\title{
THE SOCIAL CAPITAL IN COMMUNITY PREPAREDNESS TOWARDS THE LANDSLIDE DISASTER IN PAGERHARJO KULONPROGO
}

\author{
Dina Ruslanjari and Titis Puspita Dewi \\ Graduate School of Universitas Gadjah Mada \\ Email:dienarus@ugm.ac.id
}

\begin{abstract}
ABSTRAK
Penelitian ini dilakukan di Desa Pagerharjo, Kulonprogo, wilayah yang rawan terhadap terjadinya longsor lahan, pada bulan Juni - Agustus. Tujuan dari penelitian ini yaitu adalah menganalisis modal sosial untuk kesiapsiagaan masyarakat terhadap mitigasi bencana longsor. Metode yang digunakan adalah deskriptif kualitatif, dipilih 9 (Sembilan) dusun yang memiliki tingkat rawan longsor tinggi. Masyarakat di Desa Pagerharjo khususnya 9 (Sembilan) dusun tersebut telah memahami apabila tempat tinggalnya merupakan wilayah yang rawan sedang hingga tinggi terhadap ancaman bencana longsor, terutama ketika musim hujan tiba. Teori yang digunakan dalam penelitian ini adalah teori modal sosial Coleman. Hasil dari penelitian ini menunjukkan bahwa masyarakat Pagerharjo memiliki modal sosial dalam upaya mitigasi bencana. Masih mempunyai rasa kebersamaan yang tinggi yaitu gotong royong dalam menghadapi bencana. Mitigasi dapat berupa sosialisasi bencana, gotong-royong, mitigasi struktural, budaya, dan adanya aspek kepemimpinan. Masyarakat juga mempunyai kepercayaan lokal berasal dari nenek moyangnya yang merupakan perpaduan antara agama dan budaya dalam mitigasi bencana longsor. Kemauan melakukan transmigrasi merupakan wujud dimensi modal sosial dari rasa kebersamaan dan kepercayaan terhadap pimpinan dusun, desa dan pemerintah setempat.
\end{abstract}

Kata Kunci: Kesiapsiagaan; Longsor; Modal social.

\begin{abstract}
This study examines the social capital in case of people preparedness towards landslide. This research was conducted at Pagerharjo Village, Kulonprogo District where the location is categorized as the landslide prone area. The aim of this study is to find out the social capital for people preparedness in executing the landslide mitigation at Pagerharjo Village, Menoreh Mountains, Kulonprogo District. The research used qualitative descriptive method, with 9 out of 20 hamlets were selected as samples by purposive sampling. The sampling was taken in the location that has the landslide prone to the high landslide prone. People in Pagerharjo especially in the 9 hamlets have understood that their village is medium-to-highly vulnerable areas, especially in rainy season. The theory used in this study is Coleman's social capital. The result of this research proves that the Pagerharjo people have social capital in disaster mitigation. The mitigation can be practiced as disaster socialization, mutual cooperation, structural mitigation, cultural, and leadership aspect. The community has also local belief from their ancestors which is the mixture of religion and culture in case of landslide mitigation. The willingness to transmigrate is the form of social capital dimension obtained from a sense of togetherness and trust in leaders at the levels of hamlet, village, and the local government.
\end{abstract}

Keywords: Landslide; Preparedness; Social capital. 


\section{INTRODUCTION}

The landslide susceptible area is the protected or cultivation areas that cover landslide potential zones. The landslide potential zone is the area with the terrain and geological condition that highly sensitive towards external intervention, either from a natural process or human activity as the factor of land movement, thus the landslide would likely to occur in this area. The zoning of landslide susceptible area is conducted through identification and investment of natural-physical characteristic as the stimulant factors that cause the occurrence of landslide which include the $15 \%$ until $70 \%$ of slope condition, high average of rainfall level (above 2,500 mm/year), soil condition, rock structure, area stroked by fault structure, area with ground movement, and the type of land cover/vegetation (PMPU Number 22/PRT/M/2007).

Menoreh Mountains are the area that located in Kulonprogo Regency, Special Regions of Yogyakarta. The research result in reference with a slope map shows that most of the areas of Menoreh Mountains are steep slopes $(>40 \%)$, therefore these areas are assumed to have a high to very high probability of landslide (Alam, 2014). In fact, not all the sloppy areas are associated with the probability of landslide occurrence; it depends on the slope character along with the formation material in responding to trigger force especially slope respond towards rainfall (Wahyono, 1997 in Nugroho et al, 2013). The landslide will likely occur during rain with high intensity in a long period. The continuous rain in five days with $90 \mathrm{~mm}$ / day intensity or more can increase the frequency of landslide occurrence.

This research aims to find out the social capital for people preparedness in executing the landslide mitigation at Pagerharjo Village, Menoreh Mountains, Kulon progo District. The land-use pattern is also highly influencing the slope stability. The land utilization which not compatible with the capability and supporting strength could be the cause of high probability of landslide disaster. Most of the communities depend their lives on agricultural products, therefore, the agriculture land is being intensively used for planting cloves, cocoa, cardamom, cassava, melinjo tree, enau tree, and coffee, even for a tea farm. The community used the Menoreh Mountains area as the farming and agricultural land which are not followed by decent or exact soil and water conservation. This activity aims to map the potency of landslide disaster and to identify the level of local community preparedness towards disaster mitigation as well as to conduct evaluation towards land-use in accordance with landslide disaster that occurred in Pagerharjo Village, Menoreh Mountains, Kulonprogo Regency.

Pagerharjo Village topography is between steep to very steep with $45^{\prime \prime}-80^{\prime \prime}$ slope, $15-30^{\circ} \mathrm{C}$ temperature. It has high average rainfall, range between 2,500-3,000 mm/ year. The 2011 survey mentioned that the education of local community in Pegerharjo Village consists of 14,580 junior high school graduates, 74,840 senior high school graduates, and 2,490 elementary school graduates; however, 69,750 people are working as farmers. That means that the community depends on land-use to fulfill their needs. According to the village monographic data of 2012, during that year; 23 landslide events occurred.

The Menoreh Mountains area is geomorphologically really attractive to be studied due to its historical development of their complex landscape. The complex physical condition of Menoreh Mountains resulted from the endogenic and exogenic processes that works in every rock, therefore the present landscape is created. Several rocks found in this area are sandstone, sandy marl, claystone and limestone on a Middle Eocene; andesite, andesite breccia, and tuff as the products of Menoreh Volcano activity during the Oligocene period; limestone and corals deposited on the Lower Miocene; and colluvium material deposited in the Quarter Age. The differences of rocks and the time of the rocks formation affect the soil formation rate. The process of subsequent landform development is more influenced by exogenic processes that produce river valleys and the redistribution of weathering material of rocks such as a landslide. The study of 
landslide as one of the geomorphologies and landform processes can't be separated from the study of soil as the body of nature. If the soil fertility is oriented on long-term production, then biology processes in land must be considered as in land management practices (Ariyanto, 2009). According to Joyontono (2016), the soilforming factors include the parent material, climate, organism, human, topography, and time. The land-forming factors include the parent rock, relief/topography, and process (which are influenced by climate, organism, human, and time/age). During the forming process, these factors didn't work independently but worked collectively to produce soil/ground. The ground body can be viewed generally as a dynamic media. In certain circumstances, one or more soil-forming factors can be more dominant than other factors, thus the formed soil properties become heterogeneous.

Topographic borders/lines (toposequence) is different soil circuits that related with the others because it is still controlled by the influence of topography as a factor soil forming (Buckman and Brady, 1982 in Joyontono, 2016). Upper slopes with steep slopes own free drainage, large surface flow, and small water infiltration; while the lower slopes own inhibited drainage, large water infiltration; and the valleys parts with flat or badly set basins which induce the different microclimates resulting in soil properties transformation from the upper slopes to the lower slopes and even to the valley (Gerrard, 1981 in Priyono, 2012). The soil formation rate is a quantitative proportion for a number of transformations occurring in the soil which more generally shown by the morphological properties that can be seen in the cross-section of the soil profile. The soil formation rate can be assessed through the soil color, the depth of solum, the depth and thickness of the illuviation horizon, the spread of clay in the soil profile, texture, and the soil structure where these properties can be quantitatively measured (Foth and Turk 1972; Birkeland 1999 in Priyono, 2012). The more formed soils will have more complex horizonization and more stable physical properties.
Farhi (2012) in his study entitled "Vulnerability Level and Community Preparedness Index for Landslide Disaster in Bantarkawung District, Brebes Regency", examined the vulnerability and community preparedness index of landslides in Bantarkawung District, Brebes Regency. The community preparedness index is based on the modification of the parameters of disaster preparedness made by UNESCO / ISDR and LIPI in 2006, namely: knowledge and attitudes towards disaster risk, policies and guidelines, and plans for disaster emergencies. Aldrich (2012) argues that the presence of social capital at the neighborhood level is an important asset to support recovery from a large-scale disaster.

Umar (2013) studied the community knowledge and preparedness in facing the flood disaster in Bolapapu, Kulawi Sigi District, Central Sulawesi. Based on the research, it was found that the community does not have the readiness and the actions to be conducted before, during, and after the flood thus the community needs to be provided with preparedness education and training in facing the flood. According to Aji (2015), the researcher indicated that the community preparedness of Welahan and Katileng Singolelo Village, Welahan District, Jepara Regency in the pre-disaster stage is low. Their preparedness in the emergency and postdisaster response phases are moderate, thus the community preparedness in those areas is requiring some improvements.

Marfai, et al (2017) on "The Role of Local Wisdom and Social Capital in Disaster Risk Reduction and Coastal Development", identified the local wisdom from the process of behavior and culture of the community as well as seeing the links between social capital in the community and environmental management, and between disaster risk reduction and coastal area management. Other research from Mujib (2014) explained about social and cultural capital in Aceh has become one of the triggers of social change especially with globalization, people have become easier to receive information and try to develop knowledge after the conflict and tsunami disaster. 
According to the research of Ruslanjari, et al (2016) entitled "The Socio-Cultural Influence in Community Preparedness for Enhancing Post-Disaster Capacity (Case in Northeast Alor District)", a social institution is the socio-cultural factor that has a significant influence towards capacity enhancement. The variables of preparedness component such as "preparation against disaster", and "organization membership" have a significant influence towards capacity enhancement. The enhancement of "social institution" function has to be aligned with the influencing preparedness factors such as "preparation against disaster" and "organization membership", thus the capacity enhancement model would be run effectively.

The problem in this research is regarding the social capital that grows inside the community of Pagerharjo Village in preparing against landslide disaster. The aim of this research is to analyze the social capital for community preparedness towards the landslide disaster mitigation. The social capital itself according to Cohen and Prusak in Ancok (2007) is a collection of active relationships among human beings; trust, mutual understanding, and equality of values and behaviors that bind members in a network and community that enables cooperation. According to Fukuyama in Ancok (2007), social capital is a set of shared values or informal norms among members of a community group that allows for cooperation among them. Fukuyama's argument is in line with Coleman's argument in Supono (2011) defined by its function. It is not a single entity but a variety of different entities with two elements in common; they all consisted of some aspects of social structures, and they facilitate certain actions of actors-whether persons or corporate actors-within the structure.

The basic elements in social capital includes: deep participation, network, reciprocity, trust, social norms, values, and proactive actions (Supono, 2011). Portes in Sinaga (2012) defines that social capital actually has two different meanings, namely social capital in the sense of individual and social capital in the collective sense. According to Portes, an individual can also own a social capital that is useful for his personal actualization, as well as the community groups which could own social capital that can be used in optimizing their best potential.

James Coleman defines social capital as the relationships structure between individuals that enable them to create new values. When families/relatives leave their existing kinship networks, friends, and other contacts, the value of their social capital will decrease as well (Field, 2014). The existence of social capital as an important factor for disaster management can be analyzed from the Japan earthquake disaster in the Hanshin-Awaji region (Kobe), where the participation of local and public communities in facing disaster is massive.

Based on Ife and Tesoriero (2002), there are six dimensions of local wisdom, namely local knowledge, local culture, local skills, local resources, mechanisms for local decision making, and group solidarity. These six dimensions are also social capital in society. Carter (2008) defines preparedness as an action that enables governments, organizations, communities, and individuals to respond in rapid and effective manner towards disaster situations, including in preparedness action as the preparation of disaster management, supervision and personnel training. According to BAKORNAS PB (2007), preparedness is a series of activities undertaken to anticipate disasters through organizing as well as through appropriate and efficient efforts.

This study uses qualitative methods, according to Sugiyono (2013), qualitative research is a research method based on postpositivism philosophy, used to examine the condition of natural objects where the researcher is a key instrument, data source sampling was done purposively, data collecting used triangulation techniques, and the data analysis is inductive. The results of qualitative research emphasize meaning rather than generalization.

Pagerharjo Village, Samigaluh District, Kulonprogo has 1,069.5 hectares area that consist of 20 hamlets, 1,445 families, with a population of 4,858 people. About $90 \%$ people are Muslims, and the rest are Christian 
and Catholic. Pagerharjo village is consists of three villages that have been merged namely Plono, Geger Bajing and Kalirejo. Pagerharjo village consists of 20 hamlets; Separang, Sinogo, Gegerbajing, Sarigono, Kemesu, Ngemplak, West Plono, North Kalirejo, South Kalirejo, East Plono, Kalinongko, West Nglinggo, East Nglinggo, Jetis, Beteng, Suren, Jobolawang, Ngaglik, Ngentak and Mendolo.

This research with purposive sampling technique selected 9 hamlets that have moderate levels of vulnerability-very vulnerable (high susceptibility) landslides, namely: West Nglinggo, East Nglinggo, and Mendolo, Sarigono, Separang, West and East Plono, Suren, and Beteng hamlet. Researchers conducted in-depth interviews with all hamlets (9 hamlet heads) and then triangulated the source on village heads, communities living in medium and low landslide areas. In addition, data reduction, validity and reliability have been carried out. Validity and reliability of the data were examined using source triangulation and then were analyzed using Coleman's social capital theory. Picture 1 shows the areas prone to landslides.

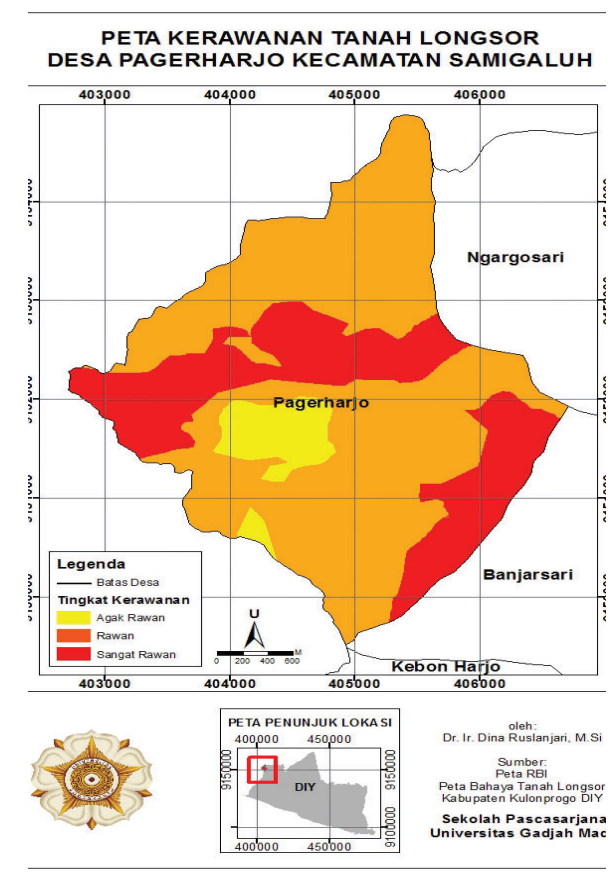

Picture 1.

Map of Landslide Vulnerability of Pagerharjo Village

Source: Researcher Analysis, 2017

\section{DISCUSSION}

The hazard that threatens the village according to the statement from the village head of Pagerharjo was a landslide aside from that the whirlwind that knocked down the wooden trees. The landslide disaster is a dominant hazard, occurring when the rainfall is in high average. The largest landslide occurred in the 1980s but only impacted the settlements and cattle pens while no casualties recorded. The landslide that occurred in 2004 in most of the hamlets has made people terrified to settle in those areas. Once there are people who are buried but still able to survive. The hamlet head had been hit by a landslide 3 years ago, which destroyed the part of his kitchen, and after the incident, the hamlet head has moved his house to another area.

The elders who live in Pagerharjo Village were already reminded the community to not build a house on the slopes or hills to avoid exposed avalanches because the area is susceptible to landslide. There is a good statement made by the village elder as what expressed by the hamlet head of West Nglinggo:

The areas with landslide historical record and determined as high susceptible area of landslide are prohibited to be used as settlement, and we would never issue a supporting document regarding the building permit. (Teguh, 50 years old, August 20 th 2017).

That danger hasn't made some people be warry; the settlements built on the slope are proving that local people have ignored the advice from their elders. This condition also resulted from the urge to own a settlement with no options left.

The villages have already own disaster response organization but the organizations are formed more in an association of function for gathering activity. This activity consists of disaster socialization and training, which is provided by Tagana (Taruna Siaga Bencana) members. The socialization had been conducted in an informal manner or at the time of scheduled meetings in the village. The training was only ever conducted once. The 
training held by Tagana members for youth was only held once. Preparedness is a series of activities carried out to anticipate disasters through organizing and through effective and efficient measures (RI Law Number 24 of 2007).

BPBD of Kulonprogo has provided emergency relief kits in the form of saws, thrusters, clothing, and logistics for the village which are used as equipment/kits when there is an emergency situation. The tools are stored in the Village Hall, in order to make it easier for the hamlet community to borrow them. Logistics are provided by Social Department of Kulonprogo, which have to always be in the warehouse thus there will be no confusion in searching for that logistics. There are also logistics purchased by using special funds provided by the Regional Government of Kulonprogo Regency. The information dissemination regarding disaster is given through the socialization from the elders for not building a house on the slopes.

The landslide disaster has changed the village economic condition. The hamlet head had the initiative to conduct transmigration because most of the people worked as farmers or loggers. The people who own their own agricultural land are only a small part of the entire community; therefore Mr. Siran from Mendolo as the hamlet head wanted to make the village community more prosperous by proposing transmigration in 2004. The transmigration was able to be realized in 2007. Mr. Siran always motivates the community to conduct transmigration in order to make their life better.

"If people are still live in the village, especially young people, then it will be difficult to change your economic condition to better circumstances" (Siran, 40 years old, August 18 ${ }^{\text {th }}$ 2017)

Coleman in Supono (2011) made an approach regarding the dimension of social capital. Transmigration has been categorized as one of the social capital dimension approaches, where togetherness is a form of a community who conduct a collective activity. Transmigration is also included in the dimension of social capital of trust, in which people have faith towards various parties. Trusts to the community leaders, in this case, are towards the Head of Hamlet and Village Head and to the Regional and Central Government.

In 2009 there were 24 families departed for transmigration to Borneo. Up to now, about $70 \%$ of the people have been transmigrated, especially the young people. The Hamlet head always visits his transmigrated citizens. When visiting the transmigration area, the hamlet head brings the art instrument such as "jathilan" to make his people feel like home there, and if they miss their hometown, that traditional art instrument would cure their homesick. Social capital has the resources and potential that exist in the community, even the community is the main social capital, which citizens or members get benefit from (Abdullah, 2013).

The community has realized that their area is prone to landslides, as mentioned by Mr. Siran from Mendolo Hamlet. Mr. Siran is a member of TAGANA who has attended the training. Landslides often occurs in Mendolo hamlet every year. The last landslide occurred three months ago. Landslides are having frequent occurrence in this area due to soil contours and the steep slopes. Sassa, et al (2009) defined landslide as the movement of rocks, debris, or the earth's surface down the slope.

"We already know that in this region there is often a landslide occurrence, especially in Mendolo hamlet, when the rainy season comes, we must be aware."

In line with Mr. Siran, Mrs. Sipon who lives near the Kukusan Hill mentioned that:

\footnotetext{
"There was often a landslide there, in April there was a huge rock rolling up from the top of the hill."
}

Understand the area is prone to landslides, a local actor is aware of the threat. The community conducts various mitigation efforts that can be categorized as local beliefs. 
The villagers in Mendolo hamlet discovered a timber plant known as Calliandra (calliandra calothyrsus), which can be used to control the erosion and prevent landslides. The leaves of the plant are used as cattle food, the leaves grows rapidly, thus it fastens the land covering and is easily decayed and quickly forms the soil humus. Its roots contains a lot of ground fertilizer (Leguminosae) that can fertilize the soil. The hamlet head is putting more confident in the Calliandra plant in comparison with the plants recommended by BPBD such as sugar palm (Arenga pinnata Merr) because the hamlet head thought that the sugar palm plant is heavy and will give extra burden to the soil that could induce landslide. Landslide is the impact of slope material movement that descending and burst out due to the influence of gravity (Van Westen et al., 2011).

Disaster management focuses on prevention, mitigation, preparedness and awareness to reduce, minimize, and soften the disaster impact (Sutanto, 2012). When the landslide is likely to occur, the local people will experience a nightmare, and feel like hearing a "tik tik tik" sound on the roof, as well as the signs from nature like heavy rain and cracks.

The local community also believe that there will be a sign of massive landslide on the hill at night, that is there will be torches everywhere just like a party/carnival of people (astral spirits). This happens in the 1980s when there was a big landslide, rain came down in the morning and in the afternoon landslide happened. This condition can't be explained by logical sense and scientific rules (Vedwan, 2006). Community preparedness is part of a mitigation process that is influenced by the disaster knowledge and experience. The factors which affect the knowledge are socio-economic and cultural factors (customs and religion).

The local community in Mendolo hamlet is more confident about the premonition in comparison with the EWS (Early Warning System) tool because they believe that hunches/premonition will be more accurate. As what expressed by the hamlet head of East Ngglinggo:

"A hundred EWS would be still less great than a hunch"

Which means that in the spots of installed EWS instrument were experiencing no actual landslide events, in fact, the landslide occurs in an area with no EWS instrument. About $80 \%$ of the area in Pagerharjo Village is a landslide potential zone. When a landslide occurs, the settlements are frequently buried in the ground but no casualties recorded.

Numbers of local community have settlements constructed of wood rather than bricks. They live in the landslide-prone areas thus if the house happens to conceive landslide potential, it can be moved immediately because the construction of wood is more flexible. When severe damage is experienced, they would report to BPBD to borrow some heavy equipment, but if only the usual damage can be solved independently.

The social capital such as togetherness is still very strong in this area. The social capital is still greatly upholding the togetherness in terms of life. When landslide occurs in their area, without prior instruction from the hamlet head for support, the men will clean up the avalanches by their own initiative, while the women cook for the consumption during the work. In this village, there is a program for house renovation using the charity fund of the community. The house renovation is aimed towards the less prosperous people or the one who need it the most. Disaster management efforts are always in contact with human victims affected by the disaster; humans who are not only physical, but also have a human spirit (Humaidi, et al., 2016).

Cardigan (2008) in Sanyal and Routray (2016) explained that the social capital conceives important role in the phase of disaster risk reduction, especially in the community level where the available resources are able to mobilize mutual interest. If social capital is successfully applied, the development of social capital is the creation of an increasingly 
independent community group that is able to participate more meaningfully in realizing good governance, including at the village level.

Table 1.

Social Capital and Disaster Mitigation Activities

\begin{tabular}{l|l}
\hline \multicolumn{1}{c|}{ Social Capital } & \multicolumn{1}{c}{ Activity } \\
\hline $\begin{array}{l}\text { Dissemination of } \\
\text { Landslides }\end{array}$ & $-\begin{array}{l}\text { Parents to their children } \\
\text { Head of hamlet to his } \\
\text { citizen }\end{array}$ \\
\hline Gotong-royong & $\begin{array}{l}\text { Donations to repair houses } \\
\text { affected by landslides }\end{array}$ \\
\hline Mtructural & $-\begin{array}{l}\text { Kaliandra plant for slope } \\
\text { reinforcement }\end{array}$ \\
$-\begin{array}{l}\text { Houses from wood } \\
\text { Transmigration of young } \\
\text { people living in landslide } \\
\text { points }\end{array}$ \\
\hline Cultural & $-\begin{array}{l}\text { A dream that means there } \\
\text { will be a disaster } \\
\text { The sounds on the roof are } \\
\text { critical, which may be the } \\
\text { lands that have fallen on } \\
\text { the roof of the house }\end{array}$ \\
\hline Leadership & $-\begin{array}{l}\text { Leadership from the hamlet } \\
\text { and village level that is } \\
\text { trusted by the community }\end{array}$ \\
\hline
\end{tabular}

Source: Researcher Analysis, 2017

\section{CONCLUSION}

The community in Pagerharjo Village has understood that their settlement area is threatened by landslide disaster from medium to high category, especially when the rainy season has arrived. Some points related to social capital such as dissemination about landslides, mutual cooperation, word of mouth and hereditary information about plants, house building, certain beliefs and leadership that lead to reduced landslide victims included in disaster mitigation. Disaster mitigation, which is often considered not requiring a correlation to social and cultural capital, turns out to be just the opposite. All aspects of social capital according to Coleman are applied by the Pagerharjo Village community to minimize the impact of the landslide disaster.

\section{BIBLIOGRAPHY}

Abdullah, Suparman. 2013. Potensi dan Kekuatan Modal Sosial dalam Suatu Komunitas. Jurnal Socius: Jurnal Sosiologi 12(1): 15-21

Aji, Ananto. 2015. Kesiapsiagaan Masyarakat Dalam Menghadapi Bencana Banjir Bandang di Kecamatan Welahan Kabupaten Jepara. Indonesian Journal of Conservation 4(1): 1-8.

Alam, T. 2014. Optimasi Pengelolaan Sistem Agroforestri Cengkeh, Kakao dan Kapulaga di Pegunungan Menoreh. Tesis. Yogyakarta: Program Pascasarjana Fakultas Pertanian, Universitas Gadjah Mada.

Aldrich, Daniel P. 2012. Building Resilience: Social Capital in Post-Disaster Recovery. Retrieved at November 4, 2018. <https:/ / www.researchgate.net/ publication/273168742_Building_ Resilience_Social_Capital_in_PostDisaster_Recovery>.

Ancok, Djamaludin. 2007. Organisasi Pembelajar (Organizational Learning). Retrieved at August 26, 2017. <http:// ancok.staff.ugm.ac.id/main/alive6-organisasi-pembelajarorganizational-learning/>.

Ariyanto, Dwi Priyo. 2009. Faktor Pembentuk Tanah Bagian 2. Retrieved at November 4, 2018. <http://ariyanto. staff.uns.ac.id/files / 2009/06/Bab02-Faktor-Pembentuk-Tanah-bag-2. pdf $>$.

Bakornas PB. 2007. Pengenalan Karakteristik Bencana dan Upaya Mitigasinya di Indonesia. Bakornas PB. Jakarta.

Carter, W. N. 2008. Disaster Management: A Disaster Manager's Handbook. Philippines: Asian Development Bank.

Desa Pagerharjo. 2012. Data Monografi Desa 2012. Pemerintah Desa Pagerharjo. Yogyakarta. $\rightarrow$ tidak tercantum 
Farhi, Zayinul, Sudibyakto, dan Hadmoko, Danang Sri. 2012. Tingkat Kerentanan dan Indeks Kesiapsiagaan Masyarakat Terhadap Bencana Tanah Longsor di Kecamatan Bantarkawung Kabupaten Brebes. MGI (Majalah Geografi Indonesia) 26(1): 80-97.

Field, John. 2014. Modal Sosial. Kreasfari Wacana. Yogyakarta.

Humaidi, M. Ali, dkk. 2016. Etnografi Bencana: Menakar Peran Para Pemimpin Lokal dalam Pengurangan Risiko Bencana. Yogyakarta: LKiS.

Ife, Jim dan Tesoriero, Frank. 2002. Community Development. Community-Based Alternatif in Age of Globalisation, Australia: Longman.

Joyontono, Puncak. 2016. Penilaian Perkembangan Tanah di Lereng Gunungapi Ijen Berdasarkan Pendekatan Pedogeomorfologi. Skripsi, Yogyakarta: Program Studi Geografi dan Ilmu Lingkungan Universitas Gadjah Mada.

Marfai, Muh. Aris; Rahayu, Esti; Triyanti, Anisa. 2017. Peran Kearifan Lokal dan Modal Sosial dalam Pengurangan Risiko Bencana dan Pembangunan Pesisir. Yogyakarta: Gadjah Mada University Press.

Mujib, Ibnu. 2014. Gagasan Aceh Baru: Pembentukan Identitas Aceh dari Dalam Reaktualisasi Ruang Publik Bagi Aksi Pengelolaan Kearifan Lokal Pasca-Konflik dan Tsunami. Junal Kawistara 4(1): 49-62.

Nugroho, Prasetyo; Soedjoko, Sri Astuti; Kusumandari, Ambar; and Marhaento, Hero. 2013. Adaptasi dan Mitigasi Bencana Tanah Longsor Melalui Penguatan Kapasitas Masyarakat dan Peningkatan Produktivitas Lahan Melalui Sistem Agroforestri. Prosiding Seminar Nasional Agroforestri (2013): 380-385

Peraturan Menteri Pekerjaan Umum Nomor 22/PRT/M/2007 Tentang Pedoman
Penataan Ruang Kawasan Rawan Bencana Longsor. Jakarta: Kementerian Pekerjaan Umum Republik Indonesia

Priyono, Kuswaji Dwi. 2012. Kajian Mineral Lempung pada Kejadian Bencana Longsor Lahan di Pegunungan Kulonprogo Daerah Istimewa Yogyakarta. Forum Geografi 26(1): 53-64

Ruslanjari, Dina; Ilyas, Awaluddin; Adhi, Bayu Kurnia; and Kinanthi, Resti. 2016. The Socio-Cultural Influence in Community Preparedness for Enhancing Post-Disaster Capacity (Case in Northeast Alor District). Prosiding International Graduate Students and Scholar's Conference in Indonesia. Sekolah Pascasarjana Universitas Gadjah Mada: 244-256.

Sanyal, S., and Routray, Jayant K. 2016. Social Capital for Disaster Risk Reduction and Management with Empirical Evidence from Sundarbans of India. International Journal of Disaster Risk Reduction 19(1): 101-111.

Sassa, K dan Canuti, P. 2009. Landslides-Disaster Risk Reduction. Germany: Springerverlag Berlin Heidelberg.

Sinaga, Rudyanto. 2012. Peran Modal Sosial dalam Mendorong Sektor Pendidikan dan Pengembangan Wilayah di Kecamatan Garoga Kabupaten Tapanuli Utara. Tesis. Program Studi Magister Teknik Perencanaan Wilayah Daerah Universitas Sumatera Utara.

Sugiyono. 2013. Metode Penelitian Kuantitatif, Kualitatif, dan Kombinasi (Mixed Method). Bandung: Penerbit Alfabeta.

Supono, Boedyo. 2011. Peranan Modal Sosial dalam Implementasi Manajemen dan Bisnis. Jurnal Ekonomi Kewirausahaan 11(1): 10-16.

Sutanto. 2012. Peranan K3 dalam Manajemen Bencana. Retrieved at November 4, 2018. <https:/ / ejournal.undip. 
ac.id/index.php/metana/article/ download/6836/559>.

Undang-Undang Republik Indonesia Nomor 24 Tahun 2007 Penanggulangan Bencana. Badan Nasional Penanggulangan Bencana. Jakarta.

Umar, Nurlailah. 2013. Pengetahuan dan Kesiapsiagaan Masyarakat Menghadapi Bencana Banjir di Bolapapu Kecamatan Kulawi Sigi Sulawesi Tengah. Jurnal Keperawatan Soedirman 8(3): 184-192
Van Westen, C.J., Alkema, D., Damen, M.C.J., Kerle, N., dan Kingma, N.C. 2011. Multi Hazard Risk Assessment: Distance Education Course. Guide Book, United Nations - ITC School on Disaster Geo-information Management.

Vedwan, Neeraj. 2006. Culture, Climate and the Environment: Local Knowledge and Perception of Climate Change among Apple Growers in Northwestern India. Journal of Ecological Anthropology 10(1): 4-16. 